\title{
IAMJ
}

INTERNATIONAL

AYURVEDIC

MEDICAL JOURNAL

\section{ROLE OF SROTODUSTI IN THE PATHOGENESIS - A CRITICAL REVIEW}

\section{$\underline{\text { Khushboo Pandey }}^{1}, \underline{\text { Sanjay Srivastava }}^{2}$}

${ }^{1}$ PG Scholar, ${ }^{2}$ Professor \& HOD

Roga Nidan PG Department, Pt. Khushilal Sharma Government (Autonomous) Ayurveda Institute, Bhopal, Madhya Pradesh, India

Corresponding Author: neetupandey9425@gmail.com

\section{https://doi.org/10.46607/iamj0809042021}

(Published online: April 2021)

Open Access

(C) International Ayurvedic Medical Journal, India 2021

Article Received: 05/03/2021 - Peer Reviewed: 19/03/2021 - Accepted for Publication: 20/03/2021

\section{(D) Check for updates}

\begin{abstract}
Many fundamental principles have been explained in Ayurveda, having specific terminology which cannot be compare with any other terminology in modern medical science and Srotas is one of them, having more functional importance rather than structural, which are enamors and Akasha Mahabhuta is mainly involves in its constitution. Srotas play a significant role in the circulation and transportation of various materials including micronutrients throughout the body, having Khavvaigunya property which provides the space for accumulation of vitiated Dosha \& Dushya. In the pathogenesis of any diseases 'Doshadusya Sammurchhana' is an important event, which happened in the Srotas and the whole process is known as Srotodusti. It is of 04 type viz. Atipravriti (Increase activity/flow), Sang (Obstruction), Siraagranthi (Reduction of the lumen of the system) \& Vimarggaman (Opposite direction flow). The management of disease depends upon Srotodusti as well as type of Srotas involved in the pathogenesis of specific disease. The characters of Srotas involve and type of Sroto Dusti affect the treatment plan and as well as the prognosis of disease.
\end{abstract}

Keywords: Srota; Sroto Dusti; Ati Pravriti; Sang; Siragranthi; Vimarggamana. 


\section{INTRODUCTION}

Srotas is an important structural as well as functional unit of the human body, for the management of disease, the complete knowledge of Srotas is must for an Ayurveda physician, to approach a patient in a holistic way. In Ayurveda classics proclaim "Srotomayam ayam hi purush". i.e. living body is a channel system. Body-mind-spirit organization has many Srotamsi, which operates the life process. Manifestation of a disease occurs in the body as a result of the malfunctioning of Srotas. Hence, any defect of Srotas must be corrected quickly, for the restoration of normal health. Any slight disturbance at the level of Srotas, either structurally or functionally (sudden or gradual) may lead to malfunction behavior of Srotas, which may result in disease if it is not corrected. "Srotamsi Khalu Parinamamapadyamananam Dhatunamabhivahini Bhavantyaayanarthena. " It means the channels of circulation carry the Dhatu undergoing transformation to their destination. The term "Parinamamapadyamananam" indicates that the channels carry such of the tissue elements as are undergoing transformation from their previous states. "Yawantah purushe Murtimanto Bhavavisheshah Tavante asmin Srotasam prakaravisheshaha." Ordinarily the word Srotas is used as a generic term indicating all the macro \& micro channels and pathways operating in the living organism. In Sushruta samhita, Srotas is defined as "Moolat khadantaram dehe prasratam tvabhivaahi yat srotastaditi vijneyam siradhamani vivarjitam" which means the structure that has Avakasha in the body spread all throughout carrying essential materials, which originates from root space except Sira \& Dhamani, ${ }^{2}$ while in Charak Samhita, Sira \& Dhamni are counted as Srotas because single vascular system which regulates the proper flow of blood and nutrition supply and clearance of waste products from Sthayi Dhatu. ${ }^{3}$

The term Srotas could refer to whole body as a single complex Srotas, each gross physiological system such as gastrointestinal system as one Srotas, a single tubular structure like nephron, each single cell of the body or sub cellular structures and membrane the receptor mechanism and networks. Srotas are extremely fine branches of bigger vessels. Srotas are with the complex pathways or channels of the nervous system governed by Vata for carrying out the functional and physiological activities of the human body. ${ }^{4}$

Aim and Objectives:

$\checkmark$ A critical review of available literature on Srotodusti.

$\checkmark$ To study the physiological and clinical significance of Srotas in the pathogenesis of diseases along with the type of Srotodusti in disease conditions.

\section{Material and Methods:}

The study was planned on a conceptual basis by using literary study of classics and modern literature as well as the pathogenesis of different disease conditions in clinical practice.

\section{Concept of Srotas:}

The term Srotas originates from Sru word which denotes to exudates or ooze, to secrete, to permeate, and to flow moving, filtering, leaking etc in which substances are secreted, circulated or transported. Human body is considered Srotomayi because the body constitutes various channels, known as Srotas. ${ }^{5}$ Srotamsi of body are channels of different kinds. It includes all channels - big or small, perceptible or imperceptible, minute or gross that composes the internal transport system of the body. ${ }^{6}$ The term Vaha, means carrying material from one place to another place and denoted for specific Srotas viz. Pranavaha, Annavaha and Udakavaha etc. Srotas can be defined in different patterns based on multifold factors viz. synonyms, structure, morphology, function and importance. "Sravanatasrotamsi" means the path where Sravanam takes place and Srotamsi are channels, which transport the Dhatu (Asthayi or Poshya Dhatu). ${ }^{7}$ Srotas are minute, spreaded long and far away like lotus stalks, in which Rasa circulates and nourishes cells\& tissues. ${ }^{8}$ In another term Sravarnat means Sravanam of Rasadiposhya Dhatu. ${ }^{5}$ The physiological entity, which transports Mana, Prana, Anna, Jala, Dhatu, and Mala etc. in body are termed as Srotas. ${ }^{9}$ Srotamsi (Channels), Sira (Veins), Dhamani (Arteries), Rasayani (Lymphatic duct), Rasavahini (Capillary), Nadi (Tubular 
structure), Panthana (Passages), Marga (Pathways, tracts), Sharirchhidrani Body orifices, openings, cavities), Samvrittaasamvrittani (Open or blind passages), Sthanani (Sites), Ashaya (Repertories), Niketa (Resort) are terms, used as synonyms of Srotas, yet they indicate different functions and structures. These Drishya and Adrishya channels indicate transport of material from one place to another in the living body.

\section{Functions of Srotamsi:}

Entire range of life processes of health and disease depends on the integrity of the Srotas, all the Dosha, Dhatu and Mala are dependent on it, for their formation, transportation and destruction. Srotamsi are not only the passage or channels for flow of various substances but also specific in their functions. These are the inner transport system of the body which provides a platform for activities of other important biofactors like three Dosha, the seven Dhatu, the Oja, the Agni, thoughts and emotions etc. Each Srotas provides nutrition to their respective Dhatu only with requisite quantities not others. Srotas are involved in transportation of both Prasada (nutrient) Dhatu as well as Mala Dhatu (waste product or product of degradation), as structure through the pores of which nutrient and waste product pass to and from the Sthayi Dhatu. It is the pre-requisite for the maintenance of good health because without healthy Srotas, the body cannot perform its normal functions, as it nourishes Sthayi Dhatu and it is concerned with the metabolic state of their corresponding tissues through different communicating mechanisms. Nutrients from Rasa Dhatu are transported to Raktavaha Srotas to replenish Rakta Dhatu. No structure in the body can grow, develop, atrophy or waste independent of Srotas, which transport Dhatus, and later on are constantly subjected to (metabolic) transformations. They sub-serve the needs of transportation and are transporters of factors, which causes the Prakopa (aggravation) or Shamana (alleviation) of Dosha.

\section{Critical Analysis of Srotovaigunya, Srotodushti \& Srotoviddha:}

Srotovaigunya is very essential for the occurrence of Vyadhi. One Srotas can be Vaigunya to the Dushti of the other Srotas. It can be understood in the Sampraptighatakas of Atisara. There is involvement of Annavaha, Udakavahasrotas and Purishavahasrotas. Thus, Annavaha, Udakavahasrotas act as Srotovaigunya to cause Purishavahasrotodushti. Srotodusti means if Srotas are in a healthy state the formation of Dosha, Dhatu and Mala are good, but when these Srotas are vitiated then Dosha, Dhatu and Mala also become vitiated and the body becomes diseased. If two persons consumed the same Nidana, but the Srotovaigunyata is different, which results in the form of two different diseases, though their Srotodushti type remains the same. e.g. If person A works on computer and strains his neck all the time and person B is teacher by profession and stands for long time in the same posture strains his knees more and if both consumed Vatakar Nidana, then person A is more prone to develop Greevashoola and Person B more prone to $\mathrm{Ja}$ nushoola, which are two different diseases. Srotovid$d h a$, the basic meaning of Viddha is pierce. It is nothing but Anatomical Deformity. Srotodushti and Srotoviddha are two different phenomena. e.g. In Pranavahasrotas the Dushtilakshan are Atisrishta, Atibaddha, Kupita, Alpaalpa, Abhikshna, Sashabdhashoolashwasa and the treatment to be followed is Shwasachikitsa, Whereas in pranavaha sroto mula viddha lakshanas are Akroshana, Vinamana, Mohana, Bhramana, Vepana and Marana which are fatal. Thus, differentiating Dushti and Viddha lakshanas is very important. ${ }^{10}$

\section{Role of Strotodushti in Pathogenesis:}

The complete knowledge of Srotodushti in the pathogenesis of specific disease is necessary for its holistic management, which helps to normalize vitiated Dosha in its Mulasthana and results in the form of curing the disease in a complete manner. The Moolsthana of Srotas as Prabhavsthana means the anatomical seat of respective Srotas and it is the main site of pathology of that Srotas. In some or other way Moolsthana of any Srotas is concerned with the seat of metabolism, origin of pathological changes, having diagnostic red flag symptoms or it may be the focus of treatment. In the manifestation of any disease, Srotodushti is an important factor. In the process of Sthanasamshraya is 
$4^{\text {th }}$ stage of Shadakriyakala, where in vitiated Doshas are spreading in a particular region where due to availability of Khavaigunya, ${ }^{11}$ the process of Doshadushyasammurchna occurs and at this stage predominal symptoms of diseases appear. In term prakupita Dosha are moving in the body, produces disease after lodging in Srotovaigunya and Doshadushyasammurchana. "Khavaigunyatitisroto Vaigunyatitiartaha" 12 it need not necessarily produce any disease until there is Doshadushyasammurchana. Agnimandya and $\mathrm{Ni}$ dansevan leads to Srotovaigunya or functional disturbance of the Srotas, it stands for some inherent weakness or lack of natural immunity to some specific disease, which may be followed by structural changes in them, it may lead to Srotorodha. In Vatakalakaliya Adhyaya, function of Vata Dosha is described as 'Sthulanu-srotasam cha bhetta'. ${ }^{13}$ This is the evidence to say that classification of 'Srotas' into Sthulasrotas and Anusrotas existed, in modern science it can be correlated with macro and micro channels in the body respectively. By the impairment of the function integrity of the Srotas, it causes its inability to perform its normal functions. It is said "Srotomayam ayam hi purush." i.e. when Srotas are get vitiated result in common Stroto Dustilakshan in progressive manner, these symptoms of diseases can be considered as important tools for understanding of pathogenesis, Strotovaigunya happens due to deformity in Srotas structure. Movement of Tridosha i.e. Vata, Pitta and Kapha are through the entire body and through different Srotamsi. Even Manasika guna Satva and Manasika Dosha Raja and Tama, which are imperceptible by sense organs, use the entire body as vehicle and field of operation. ${ }^{14}$ Pathological conditions related to abnormalities in Srotas can be managed clinically by pacifying vitiation of Dosha. The characteristics of the morbidity of the body channels are the increased or decreased flow of their contents, knotted condition of the passages or flow of their contents in abnormal channels. By knowing the factors causing Srotodushti, the best method is to prevent those factors responsible for Srotodushti. Thus, 'Prevention is better than cure'. On the basis of symptoms, we can get the idea about the site of disease, accordingly by treating the vitiated Doshas present in the $\mathrm{Mu}$ lasthana, there is complete management of a disease from its root.

Features of Srotodushti: ${ }^{15}$ In the emerging disease 04 type of Srotodusti occurs, which may be either individually or in combination.

- Atipravritti (Increased Activity)

- Sang (Obstruction)

- Siragranthi (Reduction of the lumen of the system)

- Vimarga Gamana (Opposite Direction Flow)

Atipravritti: It is defined as Atishaya pravritti (Increased activity), which means excessive flow. When the Srotas get vitiated due to Dosha, it may lead to functional deformity which causes Atipravrutti.

* Prameha due to Medovaha Strotodushti, there is Bahumutrata

* Atidrava Mala Pravratti in Atisara

* Rasa Dhatu Atipravritti in Jalodara

* Atipravrutti of Rakta Dhatu in Adhogaraktapitta

* Atipravrutti of Bahupitta in Kamla

Sang: It's known as Srotorodha, giving rise to most of the diseases. Sanga means obstruction, Srotorodha, holding up. Due to vitiation of Dosha, Srotas affected functionally. It cannot perform its routine function of Sravanam. The flow is obstructed and leads to diseased condition.

* Mutrakrichra in Mutravaha Srotas

* Sweda Avarodha in Jwara

* Sanga of Vata in Gulma

* Sanga of purisha in Vibandha

* Sanga of Pitta due to Kapha Avarana

* Sanga of Kapha in Shakhashrita Kamala

* Sanga of Purisha in Grahani Purvaroop Avastha

* Atherosclerosis is a condition in which plaque builds up inside arteries, which causes obstruction to flow of blood.

Vimarga Gamana: At the level of Srotas, there is the flow of fluid in the affected area through channels other than its own. All the elements like Doshas, Dhatus, Malas, Lasika, Ambu, Vasa can attain Vimargagamana in different Vyadhi.

* In Bhagandara entering of Mala into Mutramarga

* In Udavarta movement of Apanavata upwards 
* In Chardi movement of the food or other material upwards

* In Raktapitta movement of Rakta entering into Mutravaha, Purishavaha, Pranavaha and Annavahasrota

* In Tamakshwasa upward movement of Vata (Udavarta)

* Accumulation of interstitial fluids in Shopha

Siragranthi: It means dilatation of veins causing obstruction to normal flow through Srotas.

* Granthi

* Arsha

* Charmakeela

* Arbuda

* Vericose vein

* Aneurysm of an artery

* Enlargements found in the bronchioles due to bronchiectasis

\section{Clinical Explanation of Siragranthi:}

In the pathogenesis of Arsha as the Nidana resulting in the vitiation of Doshas in single, combination of two or more along with Rakta, Dosha move downwards through the Mahadhamani reaching Guda and affecting the Gudavalitraya producing Arsha to the individuals suffering from Mandagni and Siragranthi by stagnation of Mala in Gudavali. ${ }^{16}$

Clinical Explanation of Atipravritti, Sanga \& Vimargagamana:

The concept of Srotodusti (Atipravritti, Sanga \& Vimargamana) can better understood in the pathogenesis of Kamla which is a syndrome, not a disease, wherein due to over production of Ranjaka Pitta the level of bile pigment increases in body. It may be the result of a complication of Pandu Roga by excessive intake of Pittaja Ahara Vihara in spite of that it may produce a separate disease without Pandu. It is well explained in Shushurta Samhita in term of 'Haymayante' i.e. it may produce at the end of Pandu Roga or at the end of any disease.

The pathogenesis of Kamla is as below ${ }^{17}$ :

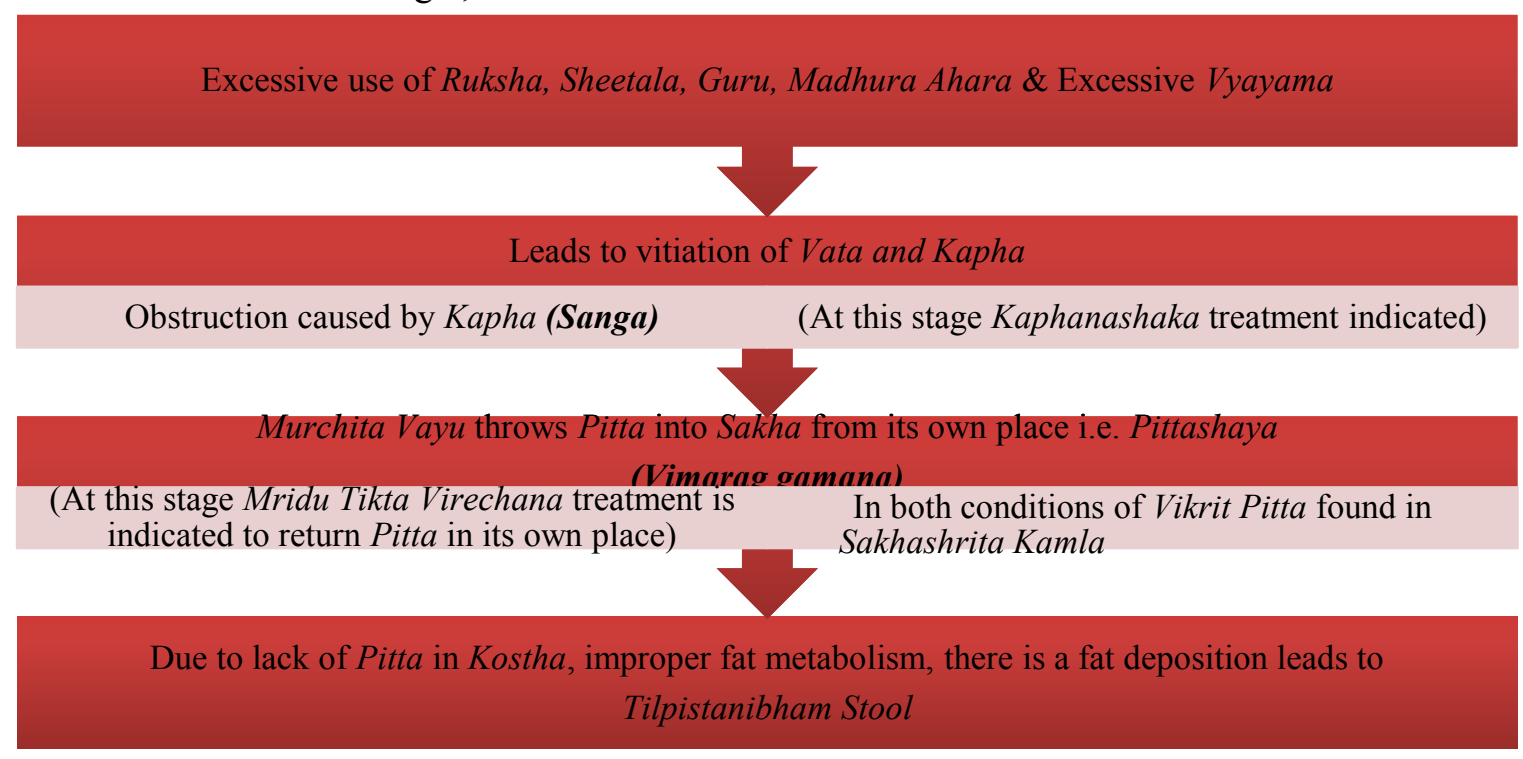

In the pathogenesis due to excessive secretion of Vikrita Pitta leads to dark yellow (Haridra) coloration of Netra, Twaka, Nakha, Mukha (Atipravritti)

\section{DISCUSSION}

Srotas is structural as well as functional unit of body. Any alteration in its structural or functional forms leads to emergence of disease conditions through viti- ation in terms of Dosha, Dhatu and Mala. For the holistic approach of management of disease, the complete knowledge of Srotas is a must for an Ayurveda physician. Dhamni and Sira are excluded from the 
preview of Srotas in Sushruta Samhita, while in Charak Samhita, Dhamni counted as Srotas because single vascular system which regulates the proper flow of blood and nutrition supply and clearance of waste products from Sthayi Dhatu. Srotasmula or origin and symptoms of pathological involvement of Srotamsi in Nija type of diseases. Term Srotoviddha been explained as inflict on their Mula The Ahara and Vihara, which aggravates the Doshas and has properties opposite to Dhatus does the vitiation of Srotas. ${ }^{26}$ When Srotas are in healthy state the regulation of Dosha, Dhatu, and Mala are good, however when Dosha, Dhatu and Mala vitiate Srotas, results in disease form. It acts as the transportation system as well as metabolism site in the body, responsible for growth and development, without Srotas no body part can grow and develop or degenerate. The internal transport system of the body is represented by Srotas and has been given a place of fundamental importance in Ayurveda both in health and disease conditions, its importance proven in the recent developments in this field. The role of Anusrotas is still not well explored in the pathogenesis of disease. At the level of Sthula Srotas, e.g. Annavahasrotas, all the physiological functions e.g. deglutination, digestion, secretion, absorption, excretion are carried out routinely in normalcy. However, if functional integrity is hampered due to vitiated Doshas, all the functions are disturbed. There is Srotovaigunyaat the site of 'Doshadushyasammurchhana' which initiates disease process. Manifestation of a disease is the result of the malfunctioning in the Srotas favouring the DoshaDushyasammurchhana. The causative factors responsible for the emergence of disease are explained in terms of Srotodushti. Thus, to restore normal health it is necessary to remove the pathological process from Srotas. Among four types of Srotodushti, Atipravritti, Sanga \& Vimarga Gamana are found in the pathogenesis at different stages of Kamla and Mridu Virechana is indicated to remove the excess bile from the body. Shakhashrita kamala needs different principles of management, since Malarupa Pitta is in Shakha and hence Virechana will not be effective. So, by giving the medicines which alleviate Kapha and Pitta is brought in Koshtha and then Pittahara Chikitsa should be given. Kamala Vyadhi is thoroughly described and helps us to understand the disease pathology very clearly. In the treatment part that is in Chikitsa sutra of Shakhashrita kamala Acharya Charaka has explained Mridu Virechana Karma. Modern science has limitations in treating the Kamla but Ayurvedic literature clearly explained pathology and treatment of Kamala, which shows the specificity of Ayurveda. In the pathogenesis of Arshas, indicates that, there is a local manifestation of systemic derangement (Stagnation in Gudwali) due to disequilibrium of Dosha, which is Siragranthi type of Srotodushti.

\section{CONCLUSION}

Srotas is nothing but the space (Avkash) defined by boundaries of Panchabhautika entity. It is unique and important structure of our body which transports essential nutrients and energy throughout the body, which helps in regulation of physiology and defence mechanism. Any obstruction, deficiency and excessiveness occur in the Srotas results in the form of ailment. All pathological lesions acute or chronic have their beginning at the level of Srotas, in Sthanasamshraya is due to Khavaigunya or Srotovaigunya the whole process is known as Doshadushyasammurchana "Api cha eke srotsam ev samudayam purusham ichanti" Apart from their normal physiological function, they are responsible for the normalcy as well as vitiation of Dosha.

Hence in view of Roga Nidan, and Chikitsa, a detailed \& clear knowledge of Srotasdusti become very much necessary as it is responsible for carrying and transformation of tissue elements by maintaining the health.

\section{REFERENCES}

1. Sharma RK and Dash B. Charak Samhita, Vol I, Chowkhambha Sanskrita Series, Varanasi, $6^{\text {th }}$ Edition; 2013. $5^{\text {th }}$ chapter Viman Sthan verse 3 Pg. 709.

2. Shusruta, Dhamanivyakarna $9^{\text {th }}$ chapter, verse 13 Sharirsthan in Murthy Shrikant KR, Susruta Samhita Vol. I, English translation Chowkhambha orientalia, Varanasi, Reprint edition; Reprint: 2014, Pg. 366. 
3. Chakrapani Dutt's Ayurveda Dipika, Chowkhambha Sanskrita Series, Varanasi, $6^{\text {th }}$ Edition; 2013. $30^{\text {th }}$ chapter Sutra Sthan verse 12 Pg. 250.

4. Swarnakar A. et al. Review article Concept of Srotas from Ayurvedic perspective with special reference to neurology, International Journal of Allied Medical Sciences and clinical Research 2014; 2(1): 36-44.

5. Chakrapani Dutt's Ayurveda Dipika, Vol I, Chowkhambha Sanskrita Series, Varanasi, $6^{\text {th }}$ Edition; 2013. $30^{\text {th }}$ chapter Sutra Sthan verse 12 Pg. 250.

6. Astanga Hridaya Angavibhag Sharira $3^{\text {rd }}$ chapter, verse 45 Sharirsthan by Murthy Shrikant KR, English translation Vol.1 Krishnadas Academy, Varanasi, Fifth edition; 2012. Pg. 254.

7. Sharma RK and Dash B. Charak Samhita, Vol I, Chowkhambha Sanskrita Series, Varanasi, $6^{\text {th }}$ Edition; 2013. $30^{\text {th }}$ chapter Sutra Sthan verse 12 Pg. 584.

8. Astanga Hridaya Angavibhag Sharira $3^{\text {rd }}$ chapter, verse 46 Sharir Sthan by Murthy Shrikant KR, English translation Vol.1 Krishnadas Academy, Varanasi, Fifth edition; 2012. Pg.717.

9. Gangasahaya Pandey, Bhavaprakasha Nighantu of Bhavamishra, Purva Khanda, chapter 3rd, verse 271 Commentary by Krishnachandra Chunekar; Chaukambha Bharati Academy, Varanasi; Reprint 2014

10. Sharma RK and Dash B. Charak Samhita (English translation), Vol I, Chowkhambha Sanskrita Series, Varanasi, $6^{\text {th }}$ Edition; 2013. $5^{\text {th }}$ chapter Viman Sthan verse7 Pg. 249.

11. Susruta, Varna Prashniya $21^{\text {th }}$ chapter, verse 33, Susruta Samhita Vol. I, Chowkhambha orientalia, Varanasi, Reprint edition; Reprint: 2014, Pg. 133.

12. Susruta, Varna Prashniya $21^{\text {th }}$ chapter, verse 33 Sutra Sthan in Murthy Shrikant KR, Susruta Samhita Vol. I, commentary of Dalhan, Chowkhambha orientalia, Varanasi, Pg. 119.

13. Sharma RK and Dash B. Charak Samhita, Vol I, Chowkhambha Sanskrita Series, Varanasi, ${ }^{\text {th }}$ Edition; 2015. $12^{\text {th }}$ chapter Vata kalakaliya, Sutra Sthan verse 12 Pg. 79.

14. Sharma RK and Dash B. Charak Samhita, Vol II, Chowkhambha Sanskrita Series, Varanasi, $6^{\text {th }}$ Edition; 2013, $9^{\text {th }}$ chapter Chikitsa Sthan verse 7 Pg.579.

15. Sharma RK and Dash B. Charak Samhita, Vol II, Chowkhambha Sanskrita Series, Varanasi, $6^{\text {th }}$ Edition; 2013. $5^{\text {th }}$ chapter Viman Sthan verse 7 Pg.250.
16. Sharma RK and Dash B. Charak Samhita, Vol II, Chowkhambha Sanskrita Series, Varanasi, $6^{\text {th }}$ Edition; 2015. $14^{\text {th }}$ chapter Arsha Chikitsa Sthan verse 9 Pg.419

17. Sharma RK and Dash B. Charak Samhita, Vol II, Chowkhambha Sanskrita Series, Varanasi, $6^{\text {th }}$ Edition; 2015. Pandu Kamla Chikitsa $16^{\text {th }}$ chapter Chikitsa Sthan verse 9 Pg.550.

\section{Source of Support: Nil Conflict of Interest: None Declared}

How to cite this URL: Khushboo Pandey \& Sanjay Srivastava: Role Of Srotodusti In The Pathogenesis - A Critical Review. International Ayurvedic Medical Journal \{online\} 2021 \{cited April, 2021\} Available from: http://www.iamj.in/posts/images/upload/736 742.pdf 